\section{A Context-Choice Model of Niche Entrepreneurship}

\author{
David B. Audretsch ${ }^{1,2}$ (iD, \\ Erik E. Lehmann ${ }^{3}$, and Julian Schenkenhofer ${ }^{3}$ (i)
}

Entrepreneurship Theory and Practice

2021, Vol. 45(5) 1276-1303

(C) The Author(s) 2020

Article reuse guidelines:

sagepub.com/journals-permissions DOI: 10.1 I 177/1042258720936042

journals.sagepub.com/home/etp

@SAGE

\begin{abstract}
Entrepreneurship research has gravitated towards a singular focus on the Silicon Valley model as the standard model of entrepreneurship. By contrast, some entrepreneurship scholars have more recently suggested embracing entrepreneurship as diverse and colorful. We build on this latter stream of literature by analyzing the diversity of entrepreneurship from complementary institutional arrangements inherent in national economies. Drawing from Robert's (2004) model of complementarities between context and organizational choice variables, we analyze the contextualization of diverging entrepreneurship models. Our findings indicate that some economies are complementary to a specialized niche strategy, while others instead promote a scalable mass-market manifestation of entrepreneurship.
\end{abstract}

\title{
Keywords
}

contextualization, entrepreneurship, niche entrepreneurship, silicon valley entrepreneurship

JEL Classification: L26, MI, P5I, ZIO

One of the most compelling challenges confronting the academic field of entrepreneurship is to move beyond the singular model and context for entrepreneurship. A narrow and one dimensional view of entrepreneurship not only restricts the analysis to certain theories and contexts but ultimately limits how entrepreneurship is understood, which contexts are to be assumed and which theoretical considerations entrepreneurship researchers are pursuing (Baker \& Welter, 2018; Welter et al., 2019). In line with this view, Welter et al. (2019) point out that "the context of most entrepreneurship research (...) was narrow, stable, and largely taken for granted." Such a narrow view predicts "a decontextualized standard model of entrepreneurship (...), which considered entrepreneurship as high-growth, technology driven, and venture capital-backed" and is "referred to as the Silicon Valley Model" (Welter et al., 2019, p. 320). Drawing from the same kind of reasoning, Welter et al. (2017) therefore call to embrace the heterogeneity of the concept. The heterogeneity inherent in a multi-context analysis of entrepreneurship can best be analyzed

\footnotetext{
'O'Neill School of Public \& Environmental Affairs, Indiana University, Bloomington, IN, USA

${ }^{2}$ Department of Innovation Management and Entrepreneurship, University of Klagenfurt, Klagenfurt, Austria

${ }^{3}$ Faculty of Business and Economics, Universität Augsburg, Germany
}

\section{Corresponding Author:}

David B. Audretsch, School of Public and Environmental Analysis, Indiana University, I3I5 East I0th Street, Bloomington, IN 47405, USA.

Email: daudrets@indiana.edu 
through the lens provided by diverse institutional contexts. The contextualization is necessary to understand the type or emergence of a particular manifestation of entrepreneurship, its intensity and frequency, and geographical location and its dynamics, in which entrepreneurship actually occurs. In light of the colorful diversity of entrepreneurship and its underlying contextualization, it may be that entrepreneurship research has been asking the wrong question. Too often, the focus of analysis has revolved around increasing more of a particular manifestation of entrepreneurship that maps on to a specific context. Unfortunately, this has sublimated even more important questions into the background, such as whether and how entrepreneurship in its many forms and manifestation differs across different contexts. A diverse view on entrepreneurship incorporates that more of it is simply not always better.

We thus align with an emerging stream in entrepreneurship research that opposes this singular view and postulates that we "should not restrict ourselves to a singular meaning of entrepreneurship, but should instead fully embrace heterogeneity and differences" (Welter et al., 2017, p. 7). From this we already know that contexts can be diverse and that contexts shape the heterogeneity of the various manifestations of entrepreneurship (Welter, 2011; Welter et al., 2017, 2019). The diversity of entrepreneurship can manifest itself in a variety of forms, which aligns to disparate geographical locations, dynamic sequences, main actors, sources of financing, social capital, and so on. Examples of different manifestations of entrepreneurship that the literature has already has pointed out in this sense are mundane entrepreneurship (Rehn \& Taalas, 2004), everyday entrepreneurship (Welter et al., 2017) and real entrepreneurship (Aldrich \& Ruef, 2018).

We examine institutional regimes at the country level, which can be described by the same context-choice variables in their complementarities, but which take on different expressions. In our context-choice model, this means that entrepreneurs either adapt to a specific context or have to change to another context. Thus, we assume the context as given. We argue that the different regimes are internally rather homogeneous and attract companies that are capable of adapting to the institutional context. Companies, which do not succeed or succeed worse than others in achieving a strategy-environment fit are likely to be forced out of the market (Barney, 1991). Thus, adaptation is necessary to develop strategies complementary to the context.

In our contribution to literature, we derive the diversity of entrepreneurship from institutional complementarities inherent in national economic systems that embed and contextualize entrepreneurial behavior. These complementarities eventually shape a certain type of entrepreneurship that is most present in a national economy, according to its institutional toolbox. Thus, the complementarity of context and organizational choice variables constitutes the different types of entrepreneurship that we examine (niche-market and scalable entrepreneurship). Applying Robert's model of the complementarities of context and organizational choice variables is one of the novel contributions of this paper and fits into a literature strand that addresses the Varieties of Capitalism (Herrmann, 2019; Pahnke \& Welter, 2019). Thus, we focus on the diverse nature of entrepreneurship, which is where we differ from previous research on entrepreneurship that rather focused on the varying extent of entrepreneurship. We do not favor one type of entrepreneurship over another, but rather point out that different manifestations of entrepreneurship generate innovative manifestations of it. In the past, the Silicon Valley model has often been studied as the standard model. To this effect, the Mittelstand has been contrasted to it as another prime example of two very innovative and critically acclaimed types of entrepreneurship. Both models resemble archetypical examples of entrepreneurial manifestations and have grown into established and conceptually linked terms (Audretsch, 2019; Lehmann et al., 2019; Pahnke \& Welter, 2019; Welter et al., 2017, 2019). However, we extend research on this topic through taking a much broader view, as we distinguish between niche and scale entrepreneurship.

Therefore, our theoretical framework analyzes a scalable mass-market to niche strategy continuum of entrepreneurial models. While some national contexts are more conducive to 
generating world-market leaders pursing incremental innovation and niche strategies, other national contexts are more conducive to the Silicon Valley type of entrepreneurship with its emphasis on radical innovation and scale-up (Brouthers et al., 2015; Covin \& Wales, 2019; Pahnke \& Welter, 2019; Tang et al., 2017). In a comprehensive overview, we describe a set of complementary variable pairs that explain the divergence of niche and scale entrepreneurship.

While the focus of this paper lies in its conceptual analysis, section five shows that our assumptions find empirical support. We descriptively point to the diverging spread of Niche and Silicon Valley Entrepreneurship and later go on to empirically study the contextualization of Niche Entrepreneurship. Our analysis uses a unique and hand-selected dataset consisting of 217 countries to empirically investigate what kind of contexts are conducive for Niche Entrepreneurship. Potential context variables that match complementarily according to the scaleniche contextual framework include the tax regimes, corporate board regimes, the educational system, along with other national context specific characteristics.

The remainder of our study is structured as follows: the second section of the paper aligns our research with the relevant extant literature in order to illustrate our contribution. Section 3 introduces our theoretical framework. Section 4 provides a discourse of the causal linkages of the selected choice-context variable pairs. In section 5, an empirical analysis of our propositions is presented. Section 6 concludes.

\section{The Heterogeneity of Entrepreneurship as a Theory of Resource Complementarities}

For decades, the Silicon Valley model of entrepreneurship was synonymous with entrepreneurship throughout the literature, leaving a picture to be painted of too few facets and colors of the phenomenon (Welter et al., 2017). In this paper, we contrast the Silicon Valley model with another type of entrepreneurship that emulates niche strategies. We argue that economies seem to favor either one or the other, depending upon the national contexts. To this effect, we extend efforts to contextualize entrepreneurship, and use the national institutional framework to examine how niche or scale economies emerge as an entrepreneurial strategy. Thus, just not a singular type of entrepreneurship but rather disparate types of entrepreneurship enhance the economic welfare of national economies. It is fundamental to our line of reasoning that the question of contextualization lies at heart of understanding entrepreneurship as a heterogeneous phenomenon.

Reviewing the literature, a number of studies recently have challenged this homogeneous view of entrepreneurship. For example, Welter et al. (2017) argue that entrepreneurship is inherently heterogeneous depending upon the underlying context. Focusing on the context implies that the manifestation of entrepreneurial behavior and thinking is inevitably embedded in the institutional environment of an economy (Welter, 2011), and therefore the ensuing heterogeneity of entrepreneurship reflects the heterogeneity of the underlying national and institutional contexts. While each context may span across multiple geographic levels of analysis, the national level of the institutional context always corresponds to interactions with the individual level, for example, the incentives confronting the individual entrepreneur.

A number of context variables have already been analyzed in previous research, and were found to determine the type of entrepreneurial strategy and manifestation. Welter (2011) develops a typology of contexts and differs between a business, social, spatial and institutional dimension. These context dimensions affect organizational choice variables at once and suggest a dynamic role for history and time. Pahnke and Welter (2019) contrast the Silicon Valley model of entrepreneurship with the German Mittelstand model, and illustrate how distinct strategies are shaped to achieve innovativeness. This reinforces the notion that concepts such as entrepreneurial orientation have mostly been applied in a one dimensional manner in relation to the Silicon 
Valley model (Deloitte, 2016; Rauch et al., 2009; Wiklund, 1999). However, niche firms can also achieve a strong entrepreneurial orientation. As most niche entrepreneurs are family firms that serve quasi-monopolistic markets, a stream within the family business literature describes family firms as risk-averse (Morck et al., 1998; Naldi et al., 2007; Schulze et al., 2001), which hampers innovation (Zahra, 2005). However, similar to firms emulating a Silicon Valley model, niche world-market leaders are characterized by a pro-active opportunity strategy, high investments in research and development (R\&D) and a high degree of innovativeness. What distinguishes both types of firms instead, is their nature of innovation, as elaborated further below.

In order to avoid the fallacy inherent in comparing "apples (a single high-growth company) to oranges (a whole segment of the German Economy)" (Pahnke \& Welter, 2019, p. 353), we examine different market types on the same level and their corresponding strategies that either target scalable high-growth platform markets or market niches. Niche economies are characterized by contextual factors that work especially in favor of firms that tailor highly specialized, technologically sophisticated products. Market leadership is therefore often a direct result from having a quasi-monopoly within the product niche, so that internationalization serves as an essential strategy to achieve growth within the narrow market niche. Operating mostly in business to business markets, often residing in rural areas and shying away from obtaining finance on capital markets enables firms with a niche strategy to remain out of the public view. Niche market firms tend to be family owned and owner-managed, which is conducive to leadership continuity and yields benefits in terms of long-term investments in the knowledge base. By contrast, scale economies breed high-tech firms that, if they survive, can command a market value in excess of a billion dollars at their initial public offering (IPO). Firms in the scale economy context typically rely on venture capital backing and disrupt markets through radical innovation. While often residing in knowledge clusters, they capitalize on spillovers and agglomerations. Thus, both types of companies are different prime examples of their respective manifestation of entrepreneurship, for which this study explores their complementary contextualization.

While this section has highlighted contextualization to embrace entrepreneurship as heterogeneous, we add to the previous literature in this stream and establish the rationale of entrepreneurial diversity in the complementarity between contextual and organizational choice variables (Roberts, 2004). We reason that its complementary deployment explains the emergence and prevalence of a certain manifestations of entrepreneurship (scalable vs niche market entrepreneurship) within a certain national economy. Following up on this, the next section introduces our theoretical framework, building on the concept of complementarity of choice and context variables as proposed by Roberts (2004).

\section{Theoretical Framework}

This study focuses on national economies and the way that national and institutional contexts provide the platform for cohesive systems of entrepreneurship. According to this view, nations as a focal point of analysis are the key to understanding economic behavior, because they establish jurisdictions, entail historical and path-dependent grown skill and resource bases and shape government policies to maintain a competitive advantage in a particular locational and institutional context. While the contemporary globalized economy enhances the central role played by knowledge as a source of competitiveness, the capacity to innovate and the patterns of competitiveness differ largely across countries. Thus, nations have to specialize in industries, for which their national institutional patterns and resource base suits them best. We argue, that both, exogenous and endogenous factors together, constitute asset and resource complementarity (Wiklund \& Shepherd, 2009; Wright et al., 2008), leading to abnormal rents. As Roberts (2004, p. 39) shows, asset and resource complementarity follows specific or coherent patterns, and what typically 


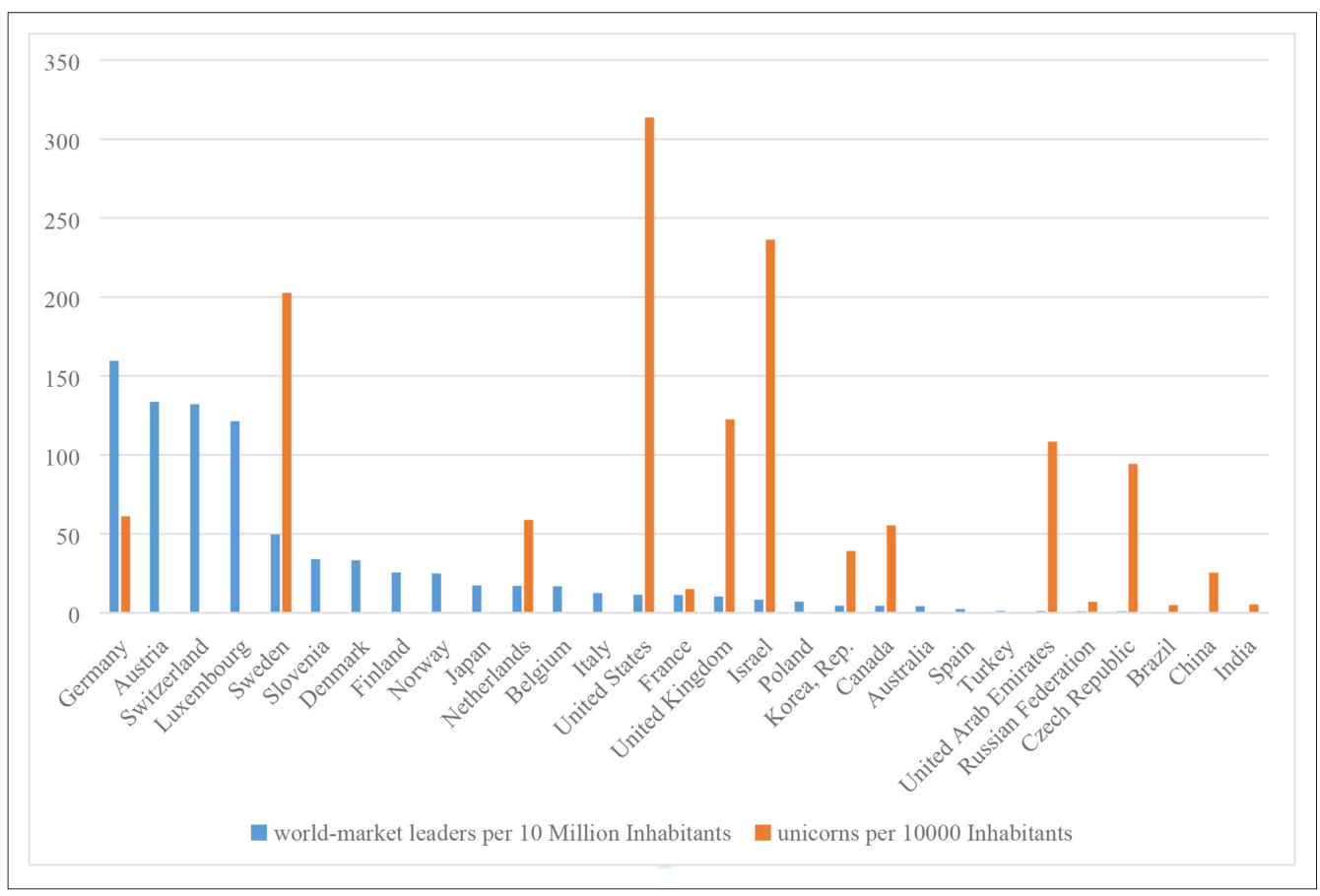

Figure I. Geographical distribution of niche and scale economies. Source. own depiction, data retrieved from Rammer and Spielkamp (2015), data of unicorns from Fortune (2017) measured as per 10 Million capita. For reasons of graphical representation the values for unicorns are per 100,000 capita.

does not work is to 'mix and match' among elements. Countries differ in their endowments, along with their norms and institutions (Chowdhury et al., 2019), taxes and legal rules, governance structures, and of course geography, leading not only to different economic outcomes (Acemoglu \& Robinson, 2015), but also to very different manifestations of entrepreneurship (Terjesen et al., 2016). Thus, entrepreneurship is not homogeneous across national and institutional contexts, but various strategies exist that enable national economies to compete internationally. Figure 1 demonstrates the geographic spread of niche and scale economies, which indicates coherent, but rather divergent patterns. Niche economies are characterized through the number of world-market leaders on a national-level, scale economies through the number of unicorns. The figure demonstrates that countries seem to specialize their entrepreneurial models in one or the other, given their distinct set of resources.

Building on this line of reasoning, we contribute to explaining the divergence of national systems of entrepreneurship through the concept of complementarities, as applied by Milgrom and Roberts (1995), Wright et al. (2008) and Wiklund and Shepherd (2009), resulting in different but coherent manifestations of entrepreneurial behavior.

A microeconomic view of complementarity refers to capital inputs for any kind of production function a manager controls. Against this backdrop, Roberts (2004) compared mass production to modern manufacturing, where two choice variables are complementary if "doing more of one of them increases the returns to doing more of the other" (Roberts, 2004, p. 34). Roberts argues that the idea of compliments and substitutes "can be extended to relations among aspects of the environment and the designer's choice variables" (2004, p. 36). In this case, "a choice variable is complementary with an element of the environment if an increase in the level of the 


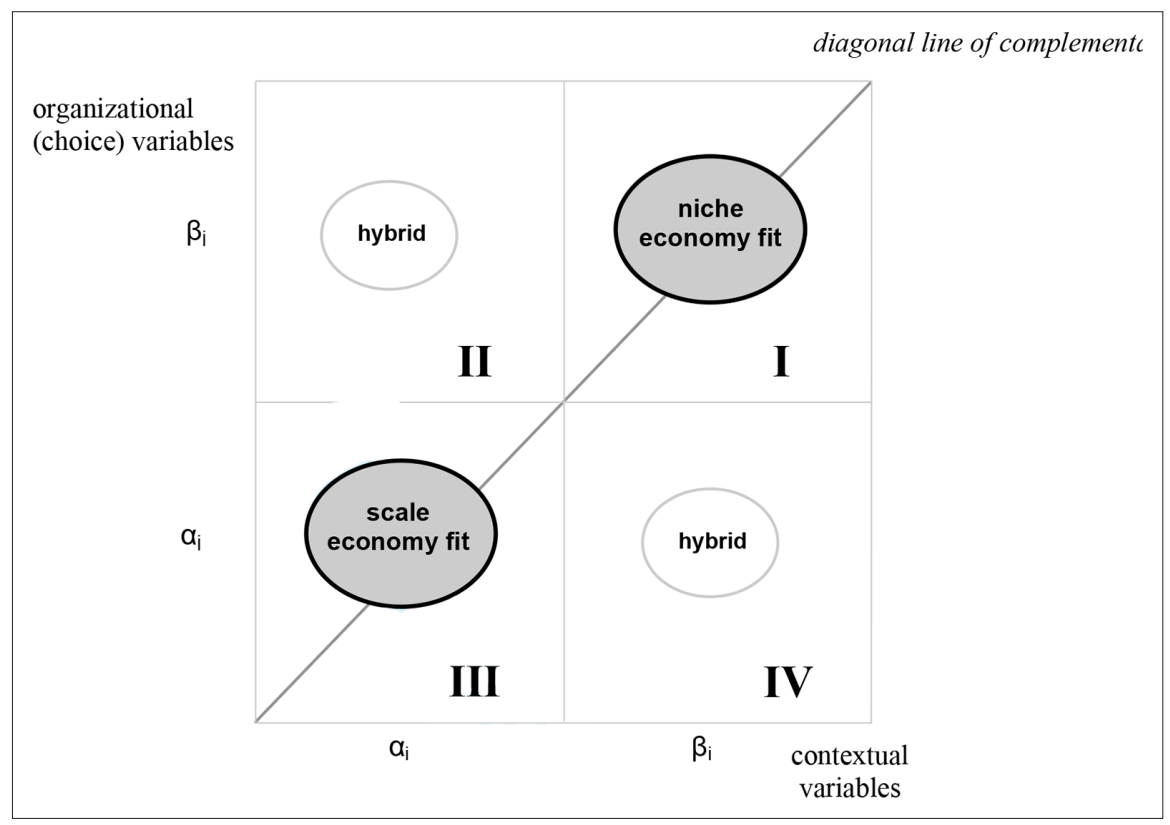

Figure 2. Theoretical framework. source. own depiction.

environmental variable increases the returns to introducing or increasing the choice variable" $(2004$, p. 36). A matching combination of two variables therefore exhibits systemic effects - the additive value of both individual variables is lower than compared to a situation of their simultaneous and complementary presence. We posit that the variation inherent in national systems of entrepreneurship and the ensuring manifestation of entrepreneurial activity mainly depends on the complementarity between contextual and organizational choice variables.

We introduce a theoretical framework that aligns the path and context dependent manifestation of entrepreneurial models and the concept of complementarity. Our framework is displayed in Figure 2. The figure displays four quadrants and adopts the view of the resource allocation of a singular economy. The model proposes that only certain pairs of variables result in paretooptimal context-choice complementarities. Here, the context variables within the model can assume two different values on the horizontal axis, as explained in the example below. The same applies to the organizational choice variables on the vertical axis. Thus, the matrix depicts different combinations of possible pairs of variables, where certain pairs have a complementary effect and thus a stronger overall effect on the economy can be expected. Context variables can assume the values $\alpha$ and $\beta$ for a characteristic i, organizational choice variables can assume the values $\alpha$ and $\beta$ for a characteristic $\mathrm{j}$. Complementary pairings are possible between $\alpha_{\mathrm{i}}$ and $\alpha_{\mathrm{j}}$ (quadrant III), as well as $\beta_{\mathrm{i}}$ and $\beta_{\mathrm{j}}$ (quadrant I). In the example, quadrant III are complementary institutional arrangements of a scale economy and quadrant I for the niche economy. The axes deliberately have no arrows and thus no scaling - quadrant III could just as well mean a niche economy fit and quadrant I a scale economy fit. It is only important that a pairing of noncomplementary variable pairs is inferior, like quadrants II and IV.

Examples for context variables include tax regimes, board systems and the educational system, while organizational choice variables include long-term management succession, family ownership control and the stock of specific human capital. Choice variables are contextual and reflect institutions and public policy, which in turn shapes the strategic fit of the organization 
adapting to the environment. In particular, our framework focuses on the requirements of complementarities resulting in heterogeneous manifestations of entrepreneurship, ranging from scale to niche strategies.

The framework illustrates that there is no one size fits all solution of variable pairs. As long as choice variables are matched complementarily, a national context may succeed in generating a unique and welfare stimulating manifestation or model of entrepreneurship. Any matches located on the diagonal line of complementarity thus maximize the size of efficiency gains from complementary choice variables. The framework shows that economic welfare maximization in a national context is compatible with a particular type and specific manifestation of entrepreneurship. Of course, the choice variables typically are not completely dichotomous, which implies that each national context will exhibit heterogeneous types of entrepreneurship.

To give an example for a context-choice variable pair, a unique institution specific to Germany, along with several other countries, such as Switzerland and Austria, is centrally organized vocational training and education (context variable) that is conducive to a particular type of skilled labor that provides niche firms with access to specialized product skills (choice variable). The high value of specific skilled labor is complementary and therefore conducive to the human resource needs compatible with the entrepreneurship niche strategy. As long as the choice variables are congruent with the specific type or manifestation of entrepreneurship, ranging from mass-market scaling to a niche strategy, economic welfare will be maximized.

To clarify our argument, we would like to give a further example for archetypical contextvariable pairs and their complementarity for niche or scale strategies. World-market leaders are mainly family firms from rural areas. An example of one of these firms is the Testo SE \& Co. KGaA, a world-market leader, which engineers measuring instruments. Firms like these benefit from soft inheritance taxation regimes, as families find it easier to establish family dynasties over generations. Testo has remained owner-managed by the Knospe family, ever since its foundation in 1957. Dualistic board structures therefore allow families to exert control on a long-term basis. Testo is located in Titisee-Neustadt, a village in the region of Breisgau-Hochschwarzwald with a population of only 12,269 , which increases the mutual lock-in of employees and employers, since outside opportunities in the labor market are only marginally available. Employees can remain rooted in their home areas through such rural companies, which increases the bond between employees and the company. Testo SE is a training company in the German VET. This means that employees are able to complete an apprenticeship in the company combining working within the company and being educated at vocational schools. In 2018, 48 apprentices started their training at Testo. The specific human capital built up in this way is particularly complementary to the human capital requirements of highly specialized niche companies.

On the other hand, Asana is a good example of a company using a scaling model. The Silicon Valley company is a unicorn and was valued at $\$ 1.5$ billion in 2018. It is a very fast growing company, as it was recently founded, in 2008, and offers productivity software. Asana uses artificial intelligence and machine learning to support the project management of companies. It primarily relies on venture capital (including $8 \mathrm{VC}$, Benchmark Capital) to finance its growth and succeeded in raising \$125 million, in 2018 alone. Thus, the company takes advantage of the more liquid traditional capital and therewith related more liquid venture capital market in the U.S., which is typical for common law countries. Finally, the Silicon Valley is an industry cluster favoring the agglomeration of high-tech companies through potential knowledge spillovers.

Drawing a conclusion, our model shows how different contexts favor the fit of complementary choice variables accordingly. In particular, we point out how different contexts shape economies on a niche to scale strategy continuum. It is important to underline that one sided stimulations of only one variable of context-choice pairs will prove to be ineffective. Stimulating 
Table I. Context Variables.

\begin{tabular}{|c|c|c|}
\hline Context & $\begin{array}{l}\text { Context variable favoring niche } \\
\text { economy }\end{array}$ & $\begin{array}{l}\text { Context variable favoring scale } \\
\text { economy }\end{array}$ \\
\hline Inheritance Taxation & $\begin{array}{l}\text { soft taxation regimes (high free } \\
\text { credits, low rates) }\end{array}$ & $\begin{array}{l}\text { strict taxation regimes (low free } \\
\text { credits, high rates) }\end{array}$ \\
\hline System of Corporate Boards & dualistic & monistic \\
\hline Legal Origin & civil law & common law \\
\hline Capital Market Development & $\begin{array}{l}\text { bank-based economies, } \\
\text { underdeveloped traditional } \\
\text { and venture capital markets }\end{array}$ & $\begin{array}{l}\text { market-based economies, liquid } \\
\text { traditional and venture capital } \\
\text { markets }\end{array}$ \\
\hline Economic Geography & $\begin{array}{l}\text { geographic decentralization, } \\
\text { localized in rural areas, } \\
\text { closed knowledge production } \\
\text { function (high vertical } \\
\text { integration) }\end{array}$ & $\begin{array}{l}\text { geographic centralization, high } \\
\text { degree of urbanization, } \\
\text { importance of knowledge clusters } \\
\text { and knowledge spillovers }\end{array}$ \\
\hline System of Vocational Education & $\begin{array}{l}\text { education as a public good; } \\
\text { important role of vocational } \\
\text { schools as provider of } \\
\text { tertiary education (specific } \\
\text { human capital) }\end{array}$ & $\begin{array}{l}\text { private investments in the skill base; } \\
\text { universities as main provider of } \\
\text { tertiary education (general human } \\
\text { capital) }\end{array}$ \\
\hline
\end{tabular}

Note. own depiction.

one of the variables of context-variable pairs, essentially requires the manipulation of the complement and vice versa.

\section{The Complementarities of Niche and Scale Economies}

This section introduces several examples of institutions that explain why some economies are more conducive to a niche entrepreneurial strategy, while others are more conducive to the entrepreneurial model of scaling up. The different institutional regimes bestow a competitive advantage of specific manifestations in particular national contexts. Table 1 gives an overview.

\section{Inheritance Taxation}

While taxes in general may influence how entrepreneurship is manifested, inheritance and gift taxation play a particularly important role. The inheritance tax generally refers to the taxation of the transfer of wealth between generations, typically as a result of death. By contrast, the gift tax refers to the taxation of wealth transfer that occurs during someone's lifetime. Most national jurisdictions treat the inheritance and gift taxes symmetrically to avoid tax avoidance strategies.

However, there is variation in the way that the inheritance tax is administered across countries. For example, the continental European countries typically levy the inheritance tax by classifying heirs according to kinship. By contrast, other countries, such as the United Kingdom and United States apply an estate tax for valuation with a flat tax that avoids subsequent classifications. Still other countries have abolished their inheritance tax, such as Canada in 1972, Portugal in 2003, Slovakia in 2004, Sweden in 2008 and Romania in 2011.

Not only does the United States not privilege close family members and family businesses, but there is a maximum tax rate of 40 percent. The high inheritance taxes not only impede the succession in family-owned businesses, but they are conducive to mass-market driven firms, 
because the owners of a business can avoid the tax burden involved with inheritance by selling the firm through an initial public offering (IPO). Thus, the tax incentives in the United States work against long-term strategic niche family businesses and instead are conducive to the more disruptive technologies and exit strategies in generating highly innovative and high growth companies, such as unicorns.

By contrast, countries with a less imposing inheritance tax, such as Switzerland, Germany and Austria may be conducive to family firms implementing a niche strategy, which often results in market leadership within the world niche. Such niche strategies are developed over long periods of time, in the organizational context of family business, where family dynasties have built their businesses across generations. This might suggest that the inheritance and gift tax regimes contribute to explaining why entrepreneurship manifests itself in mass market growth and innovative strategies in some national contexts, such as the United States, or what has been termed as the Silicon Valley model of entrepreneurship, and in strategic niches in other national contexts, such as the Mittelstand in Germany, Switzerland and Austria.

Two disparate strands of literature have analyzed the impact of the inheritance tax and gift tax on the performance and success of family business. On the hand is the strand of literature considering the inheritance tax and gift tax as a death tax, which is a financial burden that can have a deleterious impact on the investment and growth of a company, and ultimately can lead to the sale or liquidation of the company (Bjuggren \& Sund, 2001; Jestl, 2018; Tsoutsoura, 2015). In fact, studies (Carney et al., 2014; Ellul et al., 2010) have found that in those national contexts where the inheritance tax is low, inconsequential or nonexistence, family firms exhibit greater intergenerational stability and longevity (Carney et al., 2014; Ellul et al., 2010). For example, Ellul et al. (2010) provide empirical evidence that the level of investments in family firms is adversely impacted by the burden of high inheritance taxes due to liquidity constraints in those national contexts with a severe inheritance tax. They also find that the impact of the inheritance tax on family business investment is even more pronounced in those national contexts with lower protection of investors. The reason is that strong legal investor protection is conducive to financing the first-best level of investment. By contrast, in those national contexts with a weak investor protection, external finance cannot compensate for the high costs imposed by inheritance taxes.

A second strand of literature suggests that high inheritance taxes can reduce the agency costs of families (Braun et al., 2017), because the anticipated and predictable tax burden resulting from inheritance disciplines families in the consumption of private benefits. This view is based on the assumption that family leadership implies the pursuit of nonpurely economic goals for private utility maximization, thus influencing economic and firm-strategic first-best solutions: this includes the expansion of the family dynasty, even if external nonfamily leadership could be performance-enhancing, as well as any form of self-dealing, tunneling, entrenchment, and so on.

Exemplarily, there is a robust and compelling literature that has clearly found that the inheritance tax law in Germany is conducive to the intergenerational successions of its Mittelstand family firms and is attributable for the strong and sustained performance of the German Mittelstand and its longevity involving family dynasties (Carney et al., 2014; Franke et al., 2014; Houben \& Maiterth, 2011). The German Inheritance Tax Law is based on a historical protection of a sense of family and helps to maintain the unity of the family capital base, which maintains the stability of family businesses of German SMEs for generations (Carney et al., 2014). Germany introduced its inheritance tax (based on the Prussian Inheritance Tax Law of 1873) in 1906, with the children and spouses being excluded from any tax, as the Conservative Party feared the destruction of the sense of family. The heated debates surrounding the levying of an inheritance tax, and in particular the noninclusion of children and spouses, ultimately even led to the end of Reichskanzler von Bülow's tenure. Children and spouses later were included for the first time through the fiscal reforms in 1919, with a 
top rate of $35 \%$. Subsequent reforms were introduced in 1925 , with the inheritance tax law for the remainder of the twentieth century being basically based on the tax law of 1925. The tax rate of class I was reduced further to $15 \%$ and only increased later in 1974 during the social-liberal coalition. Overall, it can be concluded that the inheritance tax policy in Germany has been tax-friendly for family businesses. By contrast, a tax exemption for large corporate assets was introduced only as recently as the 1990s. In 1993, a tax allowance was introduced on business assets valued under 500.000 DM (Standortsicherungsgesetz). This tax allowance was expanded in 1996 to corporate excess of 500,000 DM at a rate of $75 \%$. In fact, the tax reform of 2009 was declared partially unconstitutional by the Federal Constitutional Court, partly because of the generous tax exemptions for family business assets, but later was permitted with certain amendments.

\section{The System of Corporate Boards}

A second element involving the institutional context of a country influencing the manifestation of entrepreneurship involves the system of corporate boards and governance. Legislation concerning the governance of corporations imposes a monistic, dualistic or hybrid structure of corporate boards. The system of corporate governance in the institutional context of the Anglo-Saxon countries consists of one tier, and is characterized by a board of directors, typically presided by a CEO and Chairperson, with the ultimate goal of maximizing the shareholder value of the company.

By contrast, the two-tier system differs by having both a management board as well as a supervisory board. While the management board is responsible for day-to-day business operations, the supervisory board controls and monitors the managers' resource allocation of corporate assets (Rouyer, 2013). The dualistic board structure is conducive to the emergence of nichefamily firms. By contrast, monistic boards are more conducive to the emergence of scalable mass-market firms, as Figure 3 underlines. This is because the separation of boards into supervisory and management functions facilitate the long-term control of the firm by the family through monitoring, approving and dismissing board managers. The independence of directors from management stands out as one of the most salient antecedents for effectively monitoring management (Corbetta \& Salvato, 2004).

While the literature on board composition has thoroughly analyzed the importance of the social and human capital of board members, Hillman and Dalziel (2003, p. 385) use the lens provided by the principal-agent model to examine the insider-outsiders interplay. In particular, they find that "dependence on the current CEO/organization creates a disincentive for insiders and dependent outsiders to side with shareholders when their interests oppose those of management," suggesting that dualistic boards enable the separation of management and control, and thus reduce agency costs (Chrisman et al., 2004, 2005; Jensen \& Meckling, 1976; Shepherd \& Haynie, 2009; Shleifer \& Vishny, 1997).

The literature has generally found the existence of a trade-off between monitoring effectiveness and agency costs. This suggests that if a family serves as owner-manager within the firm, agency costs are reduced as goal conflicts that might arise from the separation of management and control diminish (Fama \& Jensen, 1983). However, board dependence in the firm is high, which in turn reduces the effectiveness of monitoring (if the family is also present within the board).

A dualistic board system enables families to control the company through the supervisory board, because they are able to dismiss managers and therewith can exercise their control in the long-term, thus benefitting the preservation of family dynasties. By contrast, through a common level of information, unitary boards enable faster information flows, which is more conducive to 


\section{Systems of Corporate Boards}

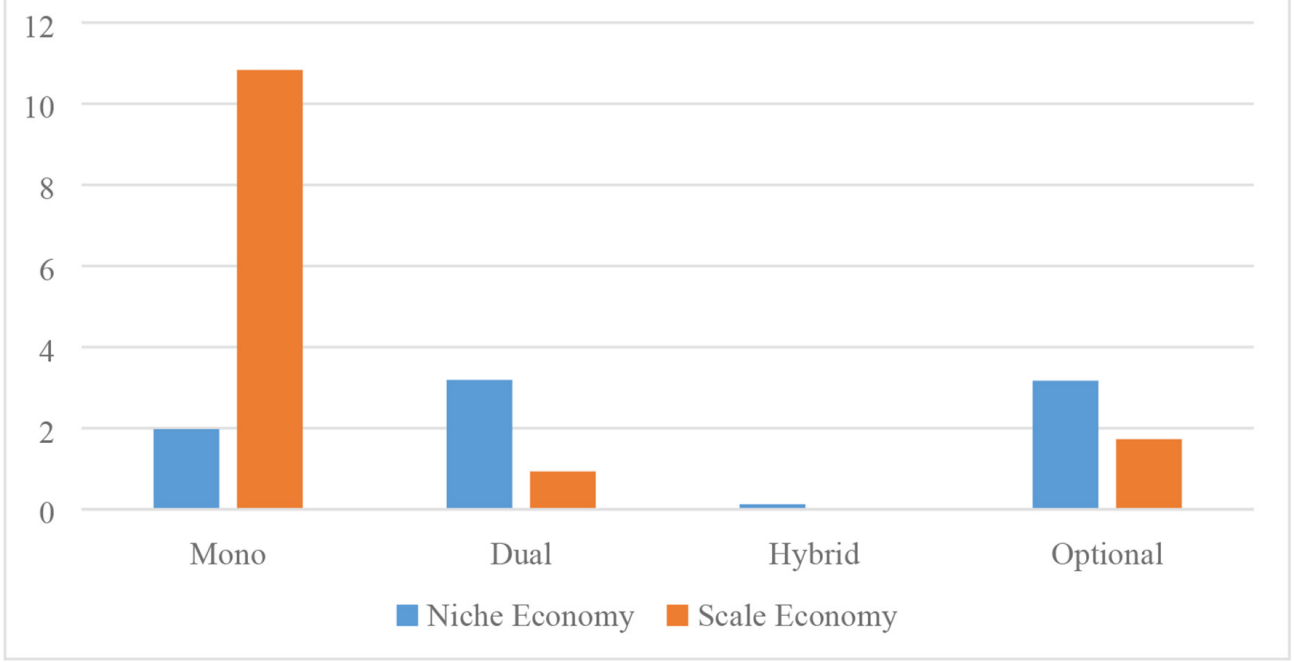

Figure 3. The distribution of world-market leaders and unicorns according the system of corporate boards. Source. own depiction, measured as per 10 Million capita. For reasons of graphical representation the values for niche economy are per 100,000 capita, the same holds for Figures 4 and 5 .

strategic and dynamic strategies, such as intermediate market adaptions (Bellavite Pellegrini \& Sironi, 2017; Bezemer et al., 2014; Millet-Reyes \& Zhao, 2010; Wollschlager \& ReuterKumpmann, 2004). Thus, a monistic board system of corporate governance is more conducive to fostering an environment for high-growth entrepreneurship characterized by radical innovation.

In the unitary board system of governance the board is not hampered by the information asymmetry that arises in the two-tier board system, where all of the relevant information for the corporate strategy that stems from employees, customers and financing, and so on reaches the supervisory board only through the management board and thus can be filtered in a strategic way ( Wollschlager \& Reuter-Kumpmann, 2004). Thus, the unitary board system of governance is able to make decisions faster and with more complete information.

\section{Legal Origin and Capital Market Development}

A third aspect of the institutional context involves the rule of law and financial capital markets. In their seminal work, La Porta et al. (1998) analyzed the development of financial markets around the world and found that investor protection was weaker in institutional contexts characterized by civil law than in institutional contexts characterized by common law. They suggest that the costs of obtaining financial capital are higher in civil law contexts, since investors receive less protection against the expropriation by corporate insiders and are therefore less willing to finance firms. Thus, residual claimants are better incentivized in the common law countries to provide external finance, while the less residual cash-flow rights are disadvantaged by the greater hazard of corporate insiders. A consequence in civil law countries is that smaller equity markets result in less market capitalization, which is crucial for early stage finance, such as the development of liquid venture capital (Black \& Gilson, 1999). Thus, shareholder-friendly environments 


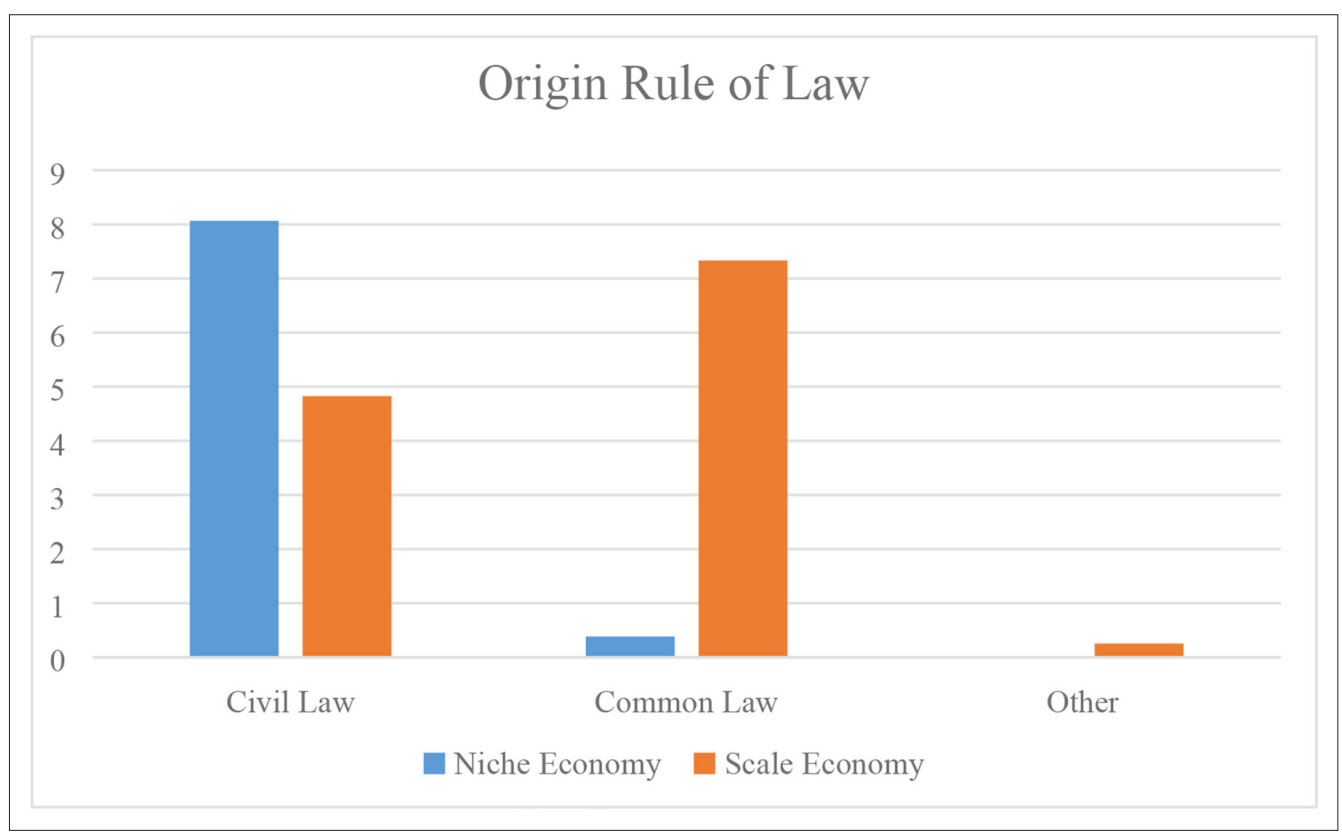

Figure 4. The distribution of world-market leaders and unicorns according to their legal origin. Source. own depiction.

support the emergence of scalable mass-market firms, because they require early stage finance and are often venture capital backed (Figure 4).

A well-developed stock market enables new ventures spurred by innovative activity to efficiently cash-out in an IPO, which in turn explains the interrelated nature of the stock and venture capital markets (Black \& Gilson, 1999). By contrast, countries with weak investor protection exhibit a high share of large block holdings. In the case of easier access to private benefits of control, concentrated ownership safeguards residual claims (Bebchuk, 1999; La Porta et al., 1999). Black and Gilson (1999) conclude that the bank-based capital market of Germany is inferior to a market-based system such as the United States, in its ability to provide liquid capital markets.

However, banks play a core role for the corporate landscape, for example, in Germany, and are the major financial intermediary there (Agarwal et al., 2001; Lehmann \& Neuberger, 2001; Levine, 2002; Vitols, 2001). Bank deposits and direct loans are the most common financial assets and liabilities in Germany (Vitols, 2001). To this effect, banks consider themselves as reliable partners for family firms in a long-term engagement, therefore incentivizing mutual specific investments in trust and knowledge. As banks monitor and advise the controlling management, a mutual incentive scheme encompasses steady, as opposed to radical, growth. Bank finance provides the perfect climate or conditions for nurturing and sustaining niche family firms.

In contrast to the bank-based financial system of Germany, the U.S. cultivated a liberal market economy that resulted in a market-based capital system assuring a liquid supply of financial capital. A stock-market centered capital market "is said to encourage short-term expectations by investors and hence short-term strategies by managers" (Black \& Gilson, 1999, p. 36), resulting in shareholder value as leading paradigm (Friedman, 1970). In contrast to bank-based financial systems, such as Germany, the market-based capital market provides the perfect climate, or conditions, to scale unicorns. In addition, shareholdings in Germany mostly are concentrated in large 
blocks and often in the hands of banks or institutional investors (Ehrhardt et al., 2006; La Porta et al., 1998), which in turn mitigates the tradability of shares and thus their liquidity, so that the requisite financing for scalable firms like unicorns is hampered.

\section{Economic Geography}

Still another dimension of the institutional context involves geographic proximity and the potential for spatially bound knowledge spillovers. Spatial proximity within knowledge clusters enables the research and development (R\&D) investments of both private industry and universities to spillover as positive externalities (Acs et al., 2009). The new knowledge created but not commercialized by those firms and organizations creating that knowledge generates new entrepreneurial opportunities (Audretsch, 2007). Such spatially localized clusters provide the perfect breeding ground for high-tech entrepreneurial firms, such as unicorns. Both unicorns and worldmarket leaders are highly innovative firms that very often produce high-tech and knowledgeintensive products. Still, both firm types differ in the way they create and absorb knowledge for their production function. World-market leaders are vertically integrated to a large extent and generally create product knowledge within the boundaries of their organization in a closed production function. By contrast, unicorns instead benefit from industrial clusters and knowledge spillovers inherent within close geographic proximity of firms and research institutes. Urban agglomerations are characterized a high population density are therefore conducive to knowledge creation and spillovers. As Porter found, clusters are typically located in urban agglomerations (Porter, 2000), where also most universities tend to be located. This would suggest that larger cities generate both more knowledge as well as a greater capacity for knowledge spillovers, which is conducive to unicorns and a scale economy. Thus, knowledge clusters result in a number of positive economies, such as attracting and sustaining human capital and fostering the commercialization of radical innovations, both of which are highly conducive for the emergence of scale economies and its unicorns.

By contrast, the niche economy relies less on highly aggregated concentrations of economic activity, but rather on leveraging the location of Mittelstand companies in rural and peripheral locations. For example, in Germany 70 percent of the world-market niche leaders are located in rural areas and span all regions of Germany. How can the surprisingly strong innovative performance of the rural world-market niche leaders (in terms of patents and R\&D) be reconciled with the knowledge spillover theory of regions, in order to understand "the spatial dimensions of innovative activity" (Audretsch \& Feldman, 2004, p. 2714)? This seemingly contradicts Krugman's (1991, p. 5) conclusion that concentration "is the most striking feature of the geography of economic activity".

The reconciliation of this apparent contradiction challenging the importance of spatially localized knowledge spillovers lies in the nature and type of innovative activity. Even though niche world-market leaders invest in R\&D and produce knowledge intensive products, their type of innovation is better characterized as incremental and not radical. They are less dependent upon knowledge spillovers and knowledge clusters as a source of knowledge. This is consistent with their location in isolated and remote rural areas, with a paucity of geographic proximity to other firms and universities. Other country-level samples of world-market leaders find support for this in various countries such as Greece (Voudouris et al., 2000), Sweden (Din et al., 2011) or Spain (Muñoz et al., 2017). In addition, their strategy of a focus on niche markets implies a high degree of specialization, limiting the potential to absorb external knowledge for specialized products. Since they are characterized as quasi-monopolists, they largely control the speed of innovation and thus product and business-life cycles within their markets, often being the sole supplier of 
products. The customer-relations often are characterized by trustful long-term relations and relational capital, with no compelling need to disrupt their own market.

Vocational schools are essential for the provision of complementary highly skilled and trained labor and more specifically, for the highly specialized niche strategy firms. Their decentralized distribution fits with the decentralized distribution of niche firms (Lehmann et al., 2019), and they are less reliant on university graduates as part of their workforce. Thus, employees often enjoy the possibility to remain located within their home regions (Fischer et al., 1998), which increases organizational identification (Mael \& Ashforth, 1992) with and loyalty to their employer (Keeble \& Tyler, 1995). Given the shortage of outside opportunities within rural labor markets, a mutual lock-in safeguards specific investments of both contractual parties. This in turn leads to long-term working relationships and investment horizons on both sides, which fits complementarily to the high degree of knowledge specialization strategy of niche firms (Audretsch et al., 2018; Baù et al., 2019). According to Mitchell et al. (2001), SMEs and the dense social networks present in rural areas increase the job embeddedness of highly place-specific human capital. Job embeddedness refers to the attachment of employees to the place they work and live in and "the extent to which people have links to other people or activities, (2) the extent to which their jobs and communities are similar to or fit with the other aspects in their life spaces, and, (3) the ease with which links can be broken" (Mitchell et al., 2001, p. 1104).

\section{The System of Vocational Education}

The educational systems of a country provide another element of the institutional context. National educational systems differ largely with regard to graduation rates of universities or vocational schools and thus the type of human capital present within the societal skill base of the workforce. According to Lehmann et al. (2019, p. 5), "in a technologically advanced economy, the societal skill base curve must stay parallel to and head of the technological implementation curve." The complementarity of skills within the societal workforce therefore is decisive to explain the divergence of niche and scale economies. While some economies hold individuals responsible for private investments in their human capital base, other economies provide it as a public good.

Lehmann et al. (2019) point out that vocational education systems that are both dual and centrally organized on a state level favor the provision of specific human capital, which is complementary to the human capital needs of niche economies as employees are better incentivized to invest their stock of specific human capital (Figure 5). For example, Germany is highly recognized for its dual apprentice system, where apprentices gain both practical and theoretical skills through firm-based training programs and upper-secondary general education within vocational schools.

Countries with centrally organized and dual vocational education systems host the highest number of niche world-market leaders. Their education systems produce a combination of general and firm-specific human capital, which best suits the complementary requirements of their specialized niche business model. Therefore, employees are willing to accept potential wage penalties from investments in their specific human capital skill base, at least partially, due to the lack of labor mobility, which is the case of the rural Mittelstand companies in Germany. This results in a mutual-lock in position for both the employer and employee, and safeguards the internalization of quasi-rents, which fosters mutual long-term investments in the skill base (Hart, 1988; Williamson, 1975) and in turn decreases the likelihood of hold-up and subsequent underinvestment of both parties (Grossman \& Hart, 1986; Hart \& Moore, 1990).

By contrast, while the striking role that universities play in the emergence of knowledge clusters is conducive for scale economies (Bercovitz \& Feldman, 2006), the high mobility rates of 


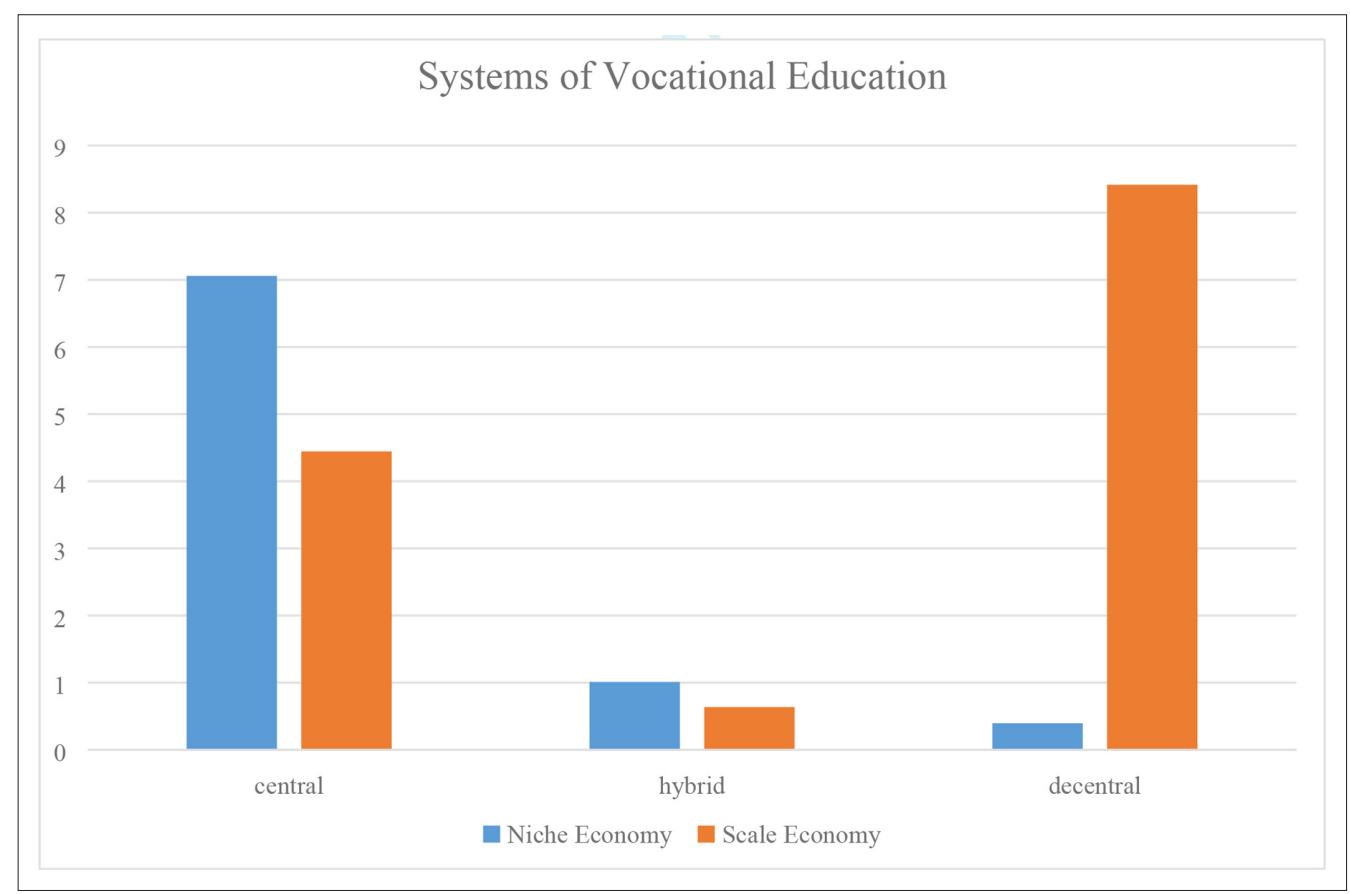

Figure 5. The distribution of world-market leaders and unicorns according to the systems of vocational education. Source. own depiction.

employees within knowledge clusters indicate that their human capital is less specific (Almeida \& Kogut, 1999). Mass higher education is more conducive to the general human capital required by scale economy firms than for the specific skills required by the niche strategy firms. The Anglo-Saxon countries have developed a decentralized education system in which individuals are urged to invest in their own skill base - public spending for education is deprioritized (Lehmann et al., 2019).

\section{Data, Method and Results}

Section four conducts an empirical analysis to test the propositions of our context-choice model as outlined above. In particular, we measure the prevalence of contextual variables and how they determine the complementary emergence of Niche Entrepreneurship within national economies. We argue that the prevalence of complementarities attracts, selects and fosters entrepreneurial firms in a specific way. Therefore, we propose that the two systems in our model are rather homogenous within their regimes, but heterogeneous to each other. Thus, the underlying null hypothesis is that the manifestation of Niche Entrepreneurship is not determined by the relevant context variables. Our data average a period comprising the years 2014-2017. Using a panel structure seemed inappropriate, as most variables display either constants or little variation. The data were hand collected and include 217 countries. Table 2 lists the variables having been used for the analysis. We relied on a variety of sources for our data such as the World Bank, the UNESCO, Cedevop (European Centre for the Development of Vocational Training), the OECD among others. Based on a broad literature review, we compile measures for the centrality and 


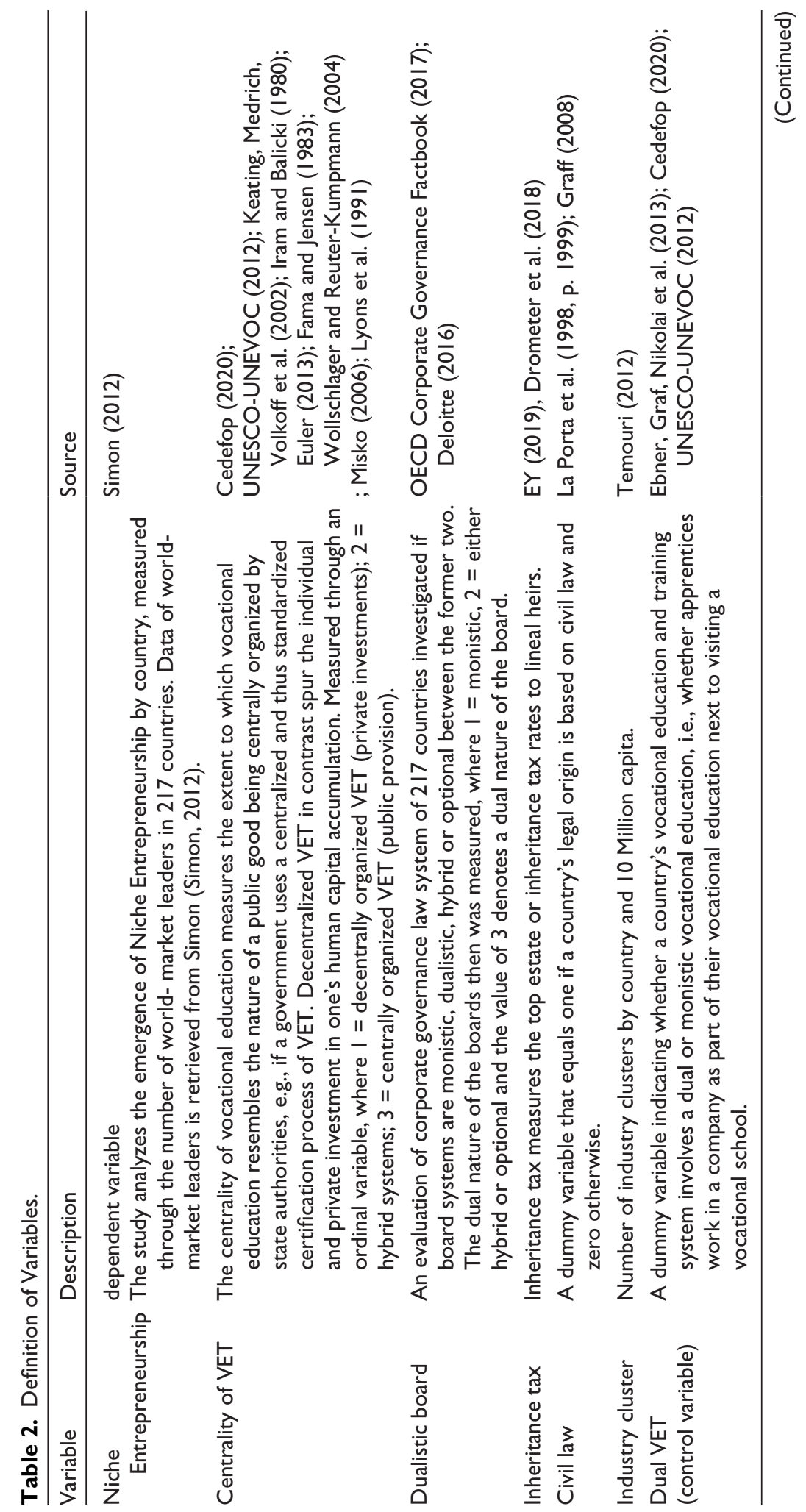




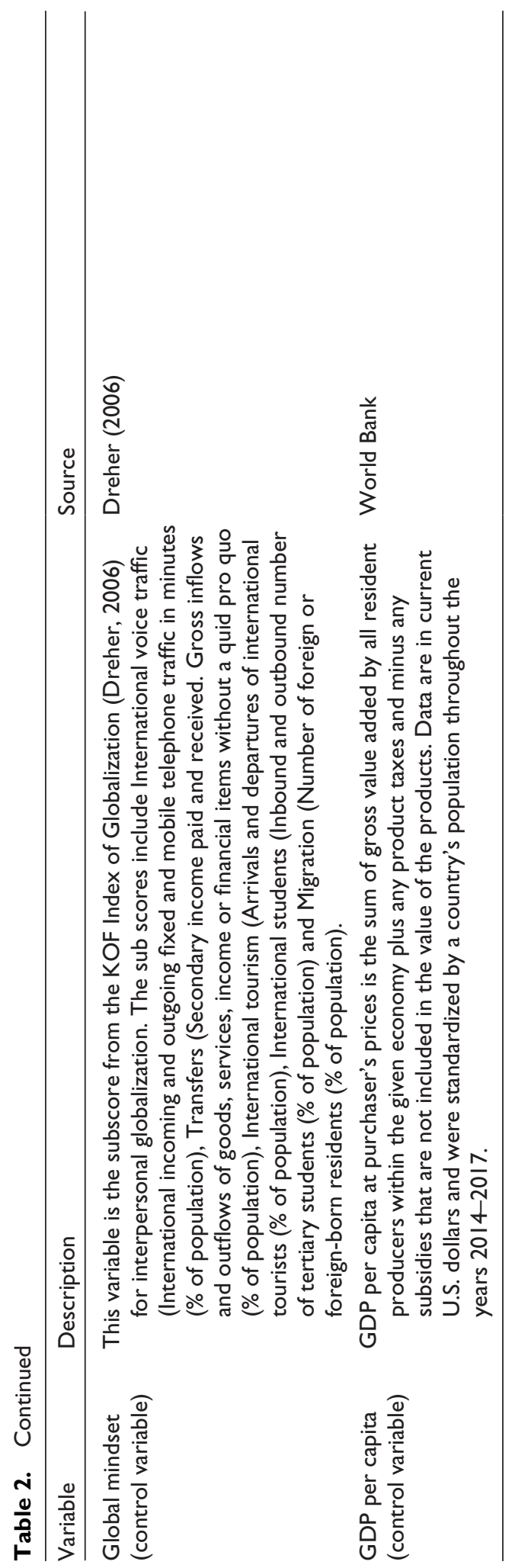


Table 3. Descriptive Statistics.

\begin{tabular}{lccccc}
\hline Variable & $\mathrm{N}$ & Mean & Sd & Min & Max \\
\hline Niche Entrepreneurship & 217 & 12.410 & 94.032 & 0 & 1,307 \\
Centrality of VET & 214 & 1.537 & 0.654 & 1 & 3 \\
Dualistic board & 211 & 1.223 & 0.528 & 1 & 3 \\
Inheritance tax & 177 & 0.081 & 0.134 & 0 & 0.550 \\
Civil law & 217 & 0.350 & 0.478 & 0 & 1 \\
Industry cluster & 217 & 0.407 & 1.886 & 0 & 21.598 \\
Dual VET & 217 & 0.051 & 0.220 & 0 & 1 \\
Global mindset & 191 & 59.388 & 22.331 & 13.471 & 98.406 \\
GDP per capita & 217 & $16,888.460$ & $24,781.790$ & 304.810 & $170,067.700$ \\
\hline
\end{tabular}

duality of vocational education, expanding earlier work on this topic (Lehmann et al., 2019). Table 2 reveals further details on how the index is composed. The same applies for the index on the dualistic nature of board systems.

The dependent variable within this study measures the worldwide emergence of Niche Entrepreneurship, operationalized by the number of world-market leaders and therefore estimated through negative binomial regressions to accord to their nature of being count data (Nunnally, 1978; Sturman, 1999). To identify whether a poisson or negative binomial regression is preferable, the literature takes the view that overdispersed data should be analyzed using negative binomial regressions. The likelihood-ratio test for the degree of overdispersion alpha shows a $\chi^{2}$ value of $1,383.18$ and thus our $\mathrm{H}_{0}(p$ value $=0.000)$ can be strongly rejected: As assumed, overdispersion is current within the data. This in turn suggests that it is preferable to use a negative binomial model over poisson. To control for size effects, we specify the logarithm of a country's population as exposure variable. Literature suggests this approach, whenever a count variable can rather be interpreted through a rate (e.g., per capita) than the mere count (Choi et al., 2016; Houston, 2007; Law et al., 2011; Qin et al., 2006; Tarko et al. (1999) ).

\section{Descriptive Statistics}

The descriptive statistics are displayed in Table 3. The dependent variable describes the emergence of Niche Entrepreneurship per country. Germany is the economy with the largest Niche Entrepreneurship sector, followed by Austria, Switzerland, Luxembourg and Sweden (per capita). Dual VET and Civil Law are binary dummy variables. The bivariate correlations as illustrated in Table 4 prove that multicollinearity between the independent and control variables is none of an issue. No correlation between the independent variables is higher than 0.772 , which it is between Global mindset and GDP per capita. The literature suggests the use of a spearman correlation coefficient whenever data is not normally distributed (Artusi et al., 2002), as it is often given for count data.

\section{Results and Discussion}

This study aims at explaining the prevalence of Niche Entrepreneurship within national economies, measured by the number of small and medium sized niche world-market leaders by country. Therefore, our empirical analysis tests the influence of selected context variables and how they determine the emergence of Niche Entrepreneurship as context-choice complementarities. 
Table 4. Matrix of Correlations.

\begin{tabular}{|c|c|c|c|c|c|c|c|c|c|}
\hline Variables & (1) & (2) & (3) & (4) & (5) & (6) & (7) & (8) & (9) \\
\hline (I) Niche Entrepreneurship & 1.000 & & & & & & & & \\
\hline (2) Centrality of VET & $0.373^{* * * * *}$ & 1.000 & & & & & & & \\
\hline (3) Dualistic board & $0.456^{* * * *}$ & $\left.0.49\right|^{* * * * *}$ & 1.000 & & & & & & \\
\hline (4) Inheritance tax & $0.181^{* *}$ & 0.095 & -0.016 & 1.000 & & & & & \\
\hline (5) Civil law & $0.312^{* * * *}$ & $0.533^{* * * *}$ & 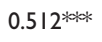 & $0.15 I^{* * *}$ & 1.000 & & & & \\
\hline (6) Industry cluster & $0.757^{* * * * *}$ & $0.292^{* * * *}$ & $0.424 * * *$ & 0.103 & $0.274^{* * * *}$ & 1.000 & & & \\
\hline (7) Dual VET & $0.474 * * *$ & $0.303 * * * *$ & $0.395 * * * *$ & 0.086 & $0.27 I^{* * * * *}$ & $0.437^{* * * *}$ & 1.000 & & \\
\hline (8) Global mindset & $0.266^{* * * * *}$ & 0.005 & $0.189 * * *$ & 0.006 & $0.141^{*}$ & $0.332 * * *$ & $0.278 * * * *$ & 1.000 & \\
\hline (9) GDP per capita & $0.420 * * * *$ & $0.127^{*}$ & $0.319 * * * *$ & $0.103 *$ & $0.189 * * *$ & $0.443 * * *$ & $0.289 * * *$ & $0.772^{* * * *}$ & 1.000 \\
\hline
\end{tabular}

Note. Spearman's correlation coefficient. $* * * * p<.01$, *** $p<.05, * p<0.1$.

Models one to five (Table 5) show the results for negative binomial regressions of our independent variables, model six shows the full model. While the dependent variable used in every model is Niche Entrepreneurship, the controls are used equally throughout each estimation process. The results for the centrality of vocational education, board systems, a country's legal origin and industry cluster show the expected results. Yet, the effect of the inheritance taxation surprises, as no effect was found. With regard to the full model, the results show that the dualistic nature of corporate boards has a strong positive effect on the emergence of Niche Entrepreneurship.

Table 5. Negative Binomial Regressions.

\begin{tabular}{|c|c|c|c|c|c|c|}
\hline & (I) & (2) & (3) & (4) & (5) & (6) \\
\hline & $\begin{array}{l}\text { Niche } \\
\text { Entrepreneurship }\end{array}$ & $\begin{array}{l}\text { Niche } \\
\text { Entrepreneurship }\end{array}$ & $\begin{array}{l}\text { Niche } \\
\text { Entrepreneurship }\end{array}$ & $\begin{array}{l}\text { Niche } \\
\text { Entrepreneurship }\end{array}$ & $\begin{array}{l}\text { Niche } \\
\text { Entrepreneurship }\end{array}$ & $\begin{array}{l}\text { Niche } \\
\text { Entrepreneurship }\end{array}$ \\
\hline Centrality of VET & $\begin{array}{c}2.346^{* * * *} \\
(0.649)\end{array}$ & & & & & $\begin{array}{l}1.387^{* *} \\
(0.67 I)\end{array}$ \\
\hline Dualistic board & & $\begin{array}{c}1.625^{\text {**** }} \\
(0.508)\end{array}$ & & & & $\begin{array}{l}\text { I. } 463^{* * * *} \\
(0.526)\end{array}$ \\
\hline Inheritance tax & & & $\begin{array}{c}2.775 \\
(2.854)\end{array}$ & & & $\begin{array}{c}2.860 \\
(2.220)\end{array}$ \\
\hline Civil law & & & & $\begin{array}{l}1.836^{*} \\
(1.090)\end{array}$ & & $\begin{array}{c}0.486 \\
(1.022)\end{array}$ \\
\hline Industry cluster & & & & & $\begin{array}{c}-0.522 \text { *** } \\
(0.229)\end{array}$ & $\begin{array}{c}-0.397 * \\
(0.238)\end{array}$ \\
\hline Dual VET & $\begin{array}{l}-1.065 \\
(1.200)\end{array}$ & $\begin{array}{l}-0.041 \\
(1.068)\end{array}$ & $\begin{array}{c}0.433 \\
(1.268)\end{array}$ & $\begin{array}{c}0.280 \\
(1.319)\end{array}$ & $\begin{array}{c}1.128 \\
(1.414)\end{array}$ & $\begin{array}{l}-0.600 \\
(1.095)\end{array}$ \\
\hline Global mindset & $\begin{array}{c}-0.054^{* *} \\
(0.025)\end{array}$ & $\begin{array}{c}-0.046^{*} \\
(0.027)\end{array}$ & $\begin{array}{c}-0.066 \text { ** } \\
(0.026)\end{array}$ & $\begin{array}{c}-0.090 * * * \\
(0.029)\end{array}$ & $\begin{array}{c}-0.072 * * * \\
(0.024)\end{array}$ & $\begin{array}{l}-0.031 \\
(0.026)\end{array}$ \\
\hline GDP per capita & $\begin{array}{c}0.000 * * * * \\
(0.000)\end{array}$ & $\begin{array}{c}0.000 \text { **** } \\
(0.000)\end{array}$ & $\begin{array}{c}0.000 * * * \\
(0.000)\end{array}$ & $\begin{array}{c}0.000^{*} * * * \\
(0.000)\end{array}$ & $\begin{array}{c}0.000^{* * * *} \\
(0.000)\end{array}$ & $\begin{array}{c}0.000 \text { **** } \\
(0.000)\end{array}$ \\
\hline Region Dummies & YES & YES & YES & YES & YES & YES \\
\hline Cons. & $\begin{array}{c}-8.668^{* * * * *} \\
(1.881)\end{array}$ & $\begin{array}{c}-7.482^{\text {**** }} \\
(1.873)\end{array}$ & $\begin{array}{c}-4.875^{* * * *} \\
(1.632)\end{array}$ & $\begin{array}{c}-4.680 \text { **** } \\
(1.612)\end{array}$ & $\begin{array}{c}-5.377^{* * * *} \\
(1.707)\end{array}$ & $\begin{array}{c}-9.295^{* * *} \\
(2.031)\end{array}$ \\
\hline Sample Size & 190 & 188 & 157 & 191 & 191 & 155 \\
\hline $\mathrm{R}^{2}$ & 0.18 & 0.18 & 0.14 & 0.15 & 0.15 & 0.19 \\
\hline
\end{tabular}

Note. Standarderrors are in parenthesis. $* * * p<0.01, * * p<0.05, * p<0.1$ 
The effects are strongly significant (p.value $<.01$ ). The results further suggest that the centrality of VET, as proposed in an earlier work by Lehmann et al. (2019), has a positive impact on the emergence of Niche Entrepreneurship, too (p.value <.05). Moreover, the full model also shows no effect for inheritance taxation. It is likely that the use of current taxation rates fails to explain the emergence of entrepreneurial models that has taken place for most of the past century. Therefore, longitudinal data comparing taxation rates for such a time frame could be more appropriate to explain the current company landscape within economies.

Civil Law, which resembles the legal origin, has a positive effect on Niche Entrepreneurship in model 4, as predicted. Within the full model instead, other explanatory variables seem to overshadow a country's legal origin. Interestingly, the Duality of VET is not as important for niche firms compared to its state-organized nature, showing no significance. Consistent with our theory, the effect of Industry clusters is negatively related to the emergence of Niche Entrepreneurship. This supports the view that decentralized economies with strong rural areas depend less on industry clusters and their knowledge spillover potential. The more economic activity is concentrated in urban agglomerations, the more difficult it is for rural areas to keep up economically. Industrial clusters draw talent and knowledge from the rural areas and thus prevent rural areas from keeping up.

Another control variable reveals interesting information. Simon (2009) argues that a global mindset is supportive for the emergence of niche firms. In our context-choice model, this would imply that a context rich of intercultural knowledge complements the internationalization strategies of niche firms (e.g., attained through foreign language education, in- and outgoing numbers of students etc.). This line of reasoning takes the view that a globalized mindset antecedes the global outreach of world-market leaders, as they sell internationally through high export rates and a high number of sales and manufacturing subsidiaries. Contrary to this, Audretsch et al. (2018) argue that this instead is attributable to the nature of narrow niche markets and technology dependence that match demand and supply. Whenever a highly specialized product is required that might be produced by only a handful of suppliers, a global mindset plays a minor role. Based on our estimations, the results back this latter notion, as it has no effect on the emergence of Niche Entrepreneurship in the full model.

\section{Conclusion}

In search of entrepreneurship champions, scholars and practitioners alike have been keen to measure, compare and contrast the extent of entrepreneurship across countries. Such comparisons warrant a singular view of entrepreneurship. This paper challenges this view and suggests that maybe we have been asking the wrong question about entrepreneurship. It may be less about who has more but rather how it is expressed differently across different institutional contexts. As Welter et al. (2017) warn, the focus has been gravitating towards the Silicon Valley model of entrepreneurship as the only bona fide characterization of entrepreneurship. By contrast, a view emerged that underlines the multiple manifestations of entrepreneurship, such as family firms and the Mittelstand. This paper has attempted to explain why the institutional national context may result in very different types or manifestations of entrepreneurship across countries. Therefore, the key contribution of this paper is to illustrate the heterogeneity of entrepreneurship manifestations through the complementarity of context-choice variables, as proposed in Robert's model (2004). Our empirical results support our model and underline the prevalence of different manifestations of entrepreneurship according to complementary institutional contexts. The theory of complementarities as known from the familiar insight of the production theory of firms also applies to various regimes of entrepreneurship manifestations. Our global sample shows that niche and Silicon Valley entrepreneurs spread as archetypical patterns in different contexts. The 
adaptation of the entrepreneurs aims to gain the best possible strategy-environment fit (Barney, 1991). Whether in a regime that is complementary for niche firms or in a regime that is complementary for scaling models, each is a rather closed system that imposes a selection process on adaptive firms. Actors that are not fit for the institutional arrangement of the economy are displaced over time, which is why we observe rather homogeneous systems that differ more among each other than internally.

The underlying theory of our study is that country specific institutions provide the framework and incentives for the organizational context manifested by entrepreneurial activity. Specific examples of such institutional aspects include the system of the inheritance tax, corporate (firm) governance, finance, locational spillovers, and education. While one institutional configuration is conducive to scale entrepreneurship, characterized by radical innovation, high growth, quick market exit and unicorns, a very different institutional configuration suggests that entrepreneurship is manifested by a long-term strategic niche strategy. Even though the firms in these two models are strikingly different, they can be characterized as being entrepreneurial. The specific contexts of a global set of national economies are compared and contrasted to explain the emergence of two different types of entrepreneurship - the Silicon Valley model with its scalability on the one hrand, and the Mittelstand with its specialized niche strategy on the other. The underlying institutional context is attributable to the resulting different manifestations of entrepreneurship. Though, the factors and contexts that have shaped complementary institutional patterns for both entrepreneurship models that originated in the U.S. (Silicon Valley Model) and Germany (Niche Family Firms) are not confined to the United States and Germany: In fact, our empirical analysis shows that these relationships appear systematically on a global level.

A further important qualification of this study is that the dichotomy characterizing the institutional context is a tendency and not discrete. Many counterexamples prevail. For example, niche strategy family firms are prevalent in the United States, such as Equinix, TransDigm and Ulta Beauty. Similarly, Germany has high performing unicorns, such as Delivery Hero, Hellofresh and Home24. Still, the model linking the underlying institutional context to the manifestation of entrepreneurial activity suggests a great propensity for niche strategy family firms, for example, in Germany, and highly innovative and high growth firms, for example, in the United States. Moreover, another important aspect revolves around the question of endogeneity. While we focus our line of reasoning on the external context to precede entrepreneurial behavior and its outcomes, we do not want to imply that entrepreneurs cannot impact the context they are surrounded with. The context, on the other hand, can essentially be shaped by the actors. We are not able to solve the problem of endogeneity ultimately (whether the context has attracted the actors or whether there is a reverse causality and the actors actually have shaped the relevant context). Among others, at least three factors explain modes how actors can shape the context: 1) companies can exploit positive spillover effects through their proximity to similar companies and thus ensure that other actors specialize in this area, 2) public policy has the possibility to shape the context through various policies (e.g., a tax reduction for venture capital or amending the taxation of profits and employee options) or 3) incumbent companies can be displaced by companies that adapt more successfully to environmental conditions and thereby shape their environment themselves, where a path-dependent change in context variables takes place.

The empirical evidence provided in this paper is consistent with the view that the underlying institutional context influences not just the amount of entrepreneurship, but also the type of entrepreneurial activity. However, using samples of specific firms to measure the size of niche and scale entrepreneurship is subject to a sampling bias. In addition, alternative measures of the inheritance tax need to be used. Perhaps most importantly is the complicated lagged structure between tax policies and the manifestation of entrepreneurship. It is the tax policies of the past decades and even centuries that may explain the different contemporary manifestations of 
entrepreneurship across institutional contexts. And finally, there are many nuanced manifestations of entrepreneurship and this paper has restricted itself to focus on two polar models. Research is mandated to highlight further manifestations of entrepreneurship and explore which contexts determine which complementarities. Therefore, this study attempts to pave the way for future research avenues.

\section{Declaration of Conflicting Interests}

The author(s) declared no potential conflicts of interest with respect to the research, authorship, and/or publication of this article.

\section{Funding}

The author(s) received no financial support for the research, authorship, and/or publication of this article.

\section{ORCID IDs}

David B. Audretsch (Di) https://orcid.org/0000-0002-3815-7762

Julian Schenkenhofer (iD) https://orcid.org/0000-0003-3502-1197

\section{References}

Acemoglu, D., \& Robinson, J. A. (2015). The rise and decline of general laws of capitalism. Journal of Economic Perspectives, 29(1), 3-28. https://doi.org/10.1257/jep.29.1.3

Acs, Z. J., Braunerhjelm, P., Audretsch, D. B., \& Carlsson, B. (2009). The knowledge spillover theory of entrepreneurship. Small Business Economics, 32(1), 15-30. https://oi.org/10.1007/s11187-0089157-3

Agarwal, R., \& Ann Elston, J., \& Elston, J. A. (2001). Bank-firm relationships, financing and firm performance in Germany. Economics Letters, 72(2), 225-232. https://doi.org/10.1016/S0165-1765( 01)00427-X

Aldrich, H. E., \& Ruef, M. (2018). Unicorns, gazelles, and other distractions on the way to understanding real entrepreneurship in the United States. Academy of Management Perspectives, 32(4), 458-472.

Almeida, P., \& Kogut, B. (1999). Localization of knowledge and the mobility of engineers in regional networks. Management Science, 45(7), 905-917. https://doi.org/10.1287/mnsc.45.7.905

Artusi, R., Verderio, P., \& Marubini, E. (2002). Bravais-Pearson and Spearman correlation coefficients: Meaning, test of hypothesis and confidence interval. The International Journal of Biological Markers, 17(2), 148-151. https://doi.org/10.1177/172460080201700213

Audretsch, D. B. (2007). The entrepreneurial society. Oxford University Press.

Audretsch, D. B. (2019). Have we oversold the silicon valley model of entrepreneurship? Small Business Economics, 78(4), 1-8. https://doi.org/10.1007/s11187-019-00272-4

Audretsch, D. B., \& Feldman, M. P. (2004). Knowledge spillovers and the geography of innovation. Handbook of regional and urban economics, 4, 2713-2739.

Audretsch, D. B., Lehmann, E. E., \& Schenkenhofer, J. (2018). Internationalization strategies of hidden champions: Lessons from Germany. Multinational Business Review, 26(1), 2-24. https://doi.org/10. 1108/MBR-01-2018-0006

Baker, T., \& Welter, F. (2018). Contextual entrepreneurship: An interdisciplinary perspective. Foundations and Trends ${ }^{\circledR}$ in Entrepreneurship, 14(4), 357-426. https://doi.org/10.1561/0300000078

Barney, J. (1991). Firm resources and sustained competitive advantage. Journal of Management, 17(1), 99-120. https://doi.org/10.1177/014920639101700108

Baù, M., Chirico, F., Pittino, D., Backman, M., \& Klaesson, J. (2019). Roots to grow: Family firms and local embeddedness in rural and urban contexts. Entrepreneurship: Theory \& Practice, 43(2), 360-385. 
Bebchuk, L. (1999). The Rent Protection Theory of Corporate Ownership and Control. Harvard Law School.

Bellavite Pellegrini, C., \& Sironi, E. (2017). Does a one-tier board affect firms' performances? Evidences from Italian unlisted enterprises. Small Business Economics, 48(1), 213-224. https://doi.org/10.1007/ s11187-016-9768-z

Bercovitz, J., \& Feldman, M. (2006). Entpreprenerial universities and technology transfer: A conceptual framework for understanding knowledge-based economic development. The Journal of Technology Transfer, 31(1), 175-188. https://doi.org/10.1007/s10961-005-5029-z

Bezemer, P.-J., Peij, S., de Kruijs, L., \& Maassen, G. (2014). How two-tier boards can be more effective. Corporate Governance: The international journal of business in society, 14(1), 15-31. https://doi.org/ 10.1108/CG-02-2013-0018

Bjuggren, P.-O., \& Sund, L.-G. (2001). Strategic decision making in intergenerational Successions of small- and medium-size family-owned businesses. Family Business Review, 14(1), 11-23. https://doi. org/10.1111/j.1741-6248.2001.00011.x

Black, B. S., \& Gilson, R. J. (1999). Does venture capital require an active stock market? Journal of Applied Corporate Finance, 11(4), 36-48. https://doi.org/10.1111/j.1745-6622.1999.tb00512.x

Braun, M., Carney, M., Duran, P., Ortiz, M., \& Riutort, J. (2017). Death and taxes: How do inheritance Tax and shareholder protection affect the market value of family firms? Working paper.

Brouthers, K. D., Nakos, G., \& Dimitratos, P. (2015). SME Entrepreneurial orientation, international performance, and the moderating role of strategic alliances. Entrepreneurship Theory and Practice, 39(5), 1161-1187. https://doi.org/10.1111/etap.12101

Carney, M., Gedajlovic, E., \& Strike, V. M. (2014). Dead money: Inheritance law and the longevity of family firms. Entrepreneurship Theory and Practice, 49(2), n/a-1283. https://doi.org/10.1111/etap. 12123

Cedefop. (2020). Vocational education and training in Europe. https://www.cedefop.europa.eu/de/tools/ vet-in-europe/systems/

Choi, Y., Tang, C. S., McIver, L., Hashizume, M., Chan, V., Abeyasinghe, R. R., Iddings, S., \& Huy, R. (2016). Effects of weather factors on dengue fever incidence and implications for interventions in Cambodia. BMC Public Health, 16(1), 241. https://doi.org/10.1186/s12889-016-2923-2

Chowdhury, F., Audretsch, D. B., \& Belitski, M. (2019). Institutions and entrepreneurship quality. Entrepreneurship Theory and Practice, 43(1), 51-81. https://doi.org/10.1177/1042258718780431

Chrisman, J. J., Chua, J. H., \& Litz, R. A. (2004). Comparing the agency costs of family and non-family firms: Conceptual issues and exploratory evidence. Entrepreneurship Theory and Practice, 28(4), 335-354. https://doi.org/10.1111/j.1540-6520.2004.00049.x

Chrisman, J. J., Chua, J. H., \& Sharma, P. (2005). Trends and directions in the development of a strategic management theory of the family firm. Entrepreneurship Theory and Practice, 29(5), 555-576. https://doi.org/10.1111/j.1540-6520.2005.00098.x

Corbetta, G., \& Salvato, C. A. (2004). The Board of directors in family firms: One size fits all? Family Business Review, 17(2), 119-134. https://doi.org/10.1111/j.1741-6248.2004.00008.x

Covin, J. G., \& Wales, W. J. (2019). Crafting high-impact entrepreneurial orientation research: Some suggested guidelines. Entrepreneurship Theory and Practice, 43(1), 3-18. https://doi.org/10.1177/ 1042258718773181

Deloitte. (2016). EMEA 360 Boardroom survey Country Profiles. https://www2.deloitte.com/content/dam/ Deloitte/global/Documents/Finance/gx-deloitte-uk-emea-360-boardroom-survey-country-profiles. pdf https://doi.org/10.2307/1494967

Din, F. U., Dolles, H., \& Middel, R. (2011). Hidden champions in Sweden: Strategies for small and medium-sized enterprises to innovate and compete successfully on the world market. University of Gothenburg. 
Dreher, A. (2006). Does globalization affect growth? Evidence from a new index of globalization. Applied Economics, 38(10), 1091-1110. https://doi.org/10.1080/00036840500392078

Drometer, M., Franko, M., Pérez, M. H., Rhode, C., Schworm, S., \& Stitteneder, T. (2018). Wealth and inheritance taxation: An overview and country comparison. (CESifo DICE Report. 16), pp. 45-54

Ebner, C., Graf, L., \& Nikolai, R. (2013). New Institutional Linkages Between Dual Vocational Training and Higher Education: A Comparative Analysis of Germany, Austria and Switzerland. In M. Windzio (Ed.), Integration and inequality in educational institutions (pp. 281-298). Springer.

Ehrhardt, O., Nowak, E., \& Weber, F. M. (2006). Running in the family-the evolution of ownership, control, and performance in German family-owned firms 1903-2003. Swiss Finance Institute Research Paper.

Ellul, A., Pagano, M., \& Panunzi, F. (2010). Inheritance law and investment in family firms. American Economic Review, 100(5), 2414-2450. https://doi.org/10.1257/aer.100.5.2414

Euler, D. (2013). Das duale System in Deutschland - Vorbild für einen Transfer Ins Ausland? Bertelsmann Stiftung.

Fama, E. F., \& Jensen, M. C. (1983). Separation of ownership and control. The Journal of Law and Economics, 26(2), 301-325. https://doi.org/10.1086/467037

Fischer, P. A., Malmberg, G., Holm, E., \& Straubhaar, T. (1998). Why do people stay? The insider advantages approach: Empirical evidence from Swedish labor markets.

Fortune. (2017). The unicorn list. http://fortune.com/unicorns

Franke, B., Simons, D., \& Voeller, D. (2014). How do employment tax credits work?: An analysis of the German inheritance Tax (ZEW Discussion Papers, 14).

Friedman, M. (1970). The social responsibility of business is to increase profit. New York Times Magazine, 122-126, 32-33.

Graff, M. (2008). Law and finance: Common law and civil law countries compared—An empirical critique. Economica, 75(297), 60-83.

Grossman, S. J., \& Hart, O. D. (1986). The costs and benefits of ownership: A theory of vertical and lateral integration. Journal of Political Economy, 94(4), 691-719. https://doi.org/10.1086/261404

Hart, O. (1988). Incomplete contracts and the theory of the firm. Journal of Law, Economics, \& Organization, $4(1), 119-139$.

Hart, O., \& Moore, J. (1990). Property rights and the nature of the firm. Journal of Political Economy, 98(6), 1119-1158. https://doi.org/10.1086/261729

Herrmann, A. M. (2019). A plea for varieties of entrepreneurship. Small Business Economics, 52(2), 331343. https://doi.org/10.1007/s11187-018-0093-6

Hillman, A. J., \& Dalziel, T. (2003). Boards of directors and firm performance: Integrating agency and resource dependence perspectives. Academy of Management Review, 28(3), 383-396. https://doi.org/ 10.5465/amr.2003.10196729

Houben, H., \& Maiterth, R. (2011). Endangering of Businesses by the German inheritance tax?-An empirical analysis. Business Research, 4(1), 32-46. https://doi.org/10.1007/BF03342725

Houston, D. J. (2007). Are helmet laws protecting young motorcyclists? Journal of Safety Research, 38(3), 329-336. https://doi.org/10.1016/j.jsr.2007.05.002

Iram, Y., \& Balicki, C. (1980). Vocational education in Switzerland and Israel: A comparative analysis. Canadian and International Education, 9(1), 95-105. https://doi.org/10.1111/j.1540-6520.2010. 00427.x

Jensen, M. C., \& Meckling, W. H. (1976). Theory of the firm: Managerial behavior, agency costs and ownership structure. Journal of Financial Economics, 3(4), 305-360. https://doi.org/10.1016/0304405X(76)90026-X

Jestl, S. (2018). Inheritance tax regimes: A comparison. Vienna Institute for international economic studies. 
Keating, J., Medrich, E., Volkoff, V., \& Perry, J. (2002). Comparative study of vocational education and training systems: National vocational education and training systems across three regions under pressure of change. NCVER.

Keeble, D., \& Tyler, P. (1995). Enterprising behaviour and the urban-rural shift. Urban Studies, 32(6), 975-997. https://doi.org/10.1080/00420989550012753

Krugman, P. (1991). Geography and trade. MIT Press.

La Porta, R., Lopez-De-Silanes, F., \& Shleifer, A. (1999). Corporate ownership around the world. The Journal of Finance, 54(2), 471-517. https://doi.org/10.1111/0022-1082.00115

La Porta, R., Lopez-de-Silanes, F., Shleifer, A., \& Vishny, R. W. (1998). Law and finance. Journal of Political Economy, 106(6), 1113-1155. https://doi.org/10.1086/250042

Law, T. H., Noland, R. B., \& Evans, A. W. (2011). The sources of the Kuznets relationship between road fatalities and economic growth. Journal of Transport Geography, 19(2), 355-365. https://doi.org/10. 1016/j.jtrangeo.2010.02.004

Lehmann, E. E., \& Neuberger, D. (2001). Do lending relationships matter? Evidence from bank survey data in Germany. Journal of Economic Behavior \& Organization, 45(4), 339-359.

Lehmann, E. E., Schenkenhofer, J., \& Wirsching, K. (2019). Hidden champions and unicorns: A question of the context of human capital investment. Small Business Economics, 52(2), 359-374. https://doi. org/10.1007/s11187-018-0096-3

Levine, R. (2002). Bank-based or market-based financial systems: Which is better? (NO. w9138). National Bureau of Economic Research.

Lyons, J. E., Randhawa, B. S., \& Paulson, N. A. (1991). The development of vocational education in Canada. Canadian Journal of Education, 16(2), 137-150.

Mael, F., \& Ashforth, B. E. (1992). Alumni and their Alma mater: A partial test of the reformulated model of organizational identification. Journal of Organizational Behavior, 13(2), 103-123. https://doi.org/ 10.1002/job.4030130202

Milgrom, P., \& Roberts, J. (1995). Complementarities and fit strategy, structure, and organizational change in manufacturing. Journal of Accounting and Economics, 19(2-3), 179-208. https://oi.org/10.1016/ 0165-4101(94)00382-F

Millet-Reyes, B., \& Zhao, R. (2010). A comparison between one-tier and two-tier board structures in France. Journal of International Financial Management \& Accounting, 21(3), 279-310.

Misko, J. (2006). Vocational education and training in Australia, the United Kingdom and Germany. National centre for vocational education research. NCVER.

Mitchell, T. R., Holtom, B. C., Lee, T. W., Sablynski, C. J., \& Erez, M. (2001). Why people stay: Using job embeddedness to predict voluntary turnover. Academy of Management Journal, 44(6), 11021121.

Morck, R. K., Stangeland, D. A., \& Yeung, B. (1998). Inherited wealth, corporate control and economic growth: The Canadian disease (NO. w6814). National Bureau of Economic Research.

Muñoz, E. P., Ripoll-i-Alcon, J., \& Silvente, V. B. (2017). Hidden champions in Spain: The path to successful business decisions. Revista de Métodos Cuantitativos para la Economía y la Empresa, 24(1), 190-208.

Naldi, L., Nordqvist, M., Sjöberg, K., \& Wiklund, J. (2007). Entrepreneurial orientation, risk taking, and performance in family firms. Family Business Review, 20(1), 33-47. https://doi.org/10.1111/j.17416248.2007.00082.x

Nunnally, J. M. (1978). Psychometric theory (2nd ed.). McGraw-Hill.

Pahnke, A., \& Welter, F. (2019). The German Mittelstand: Antithesis to silicon Valley entrepreneurship? Small Business Economics, 52(2), 345-358. https://doi.org/10.1007/s11187-018-0095-4

Porter, M. E. (2000). Location, competition, and economic development: Local clusters in a global economy. Economic Development Quarterly, 14(1), 15-34. https://doi.org/10.1177/089124240001400105 
Qin, X., Noyce, D. A., Lee, C., \& Kinar, J. R. (2006). Snowstorm event-based crash analysis. Transportation Research Record: Journal of the Transportation Research Board, 1948(1), 135-141. https://doi.org/ $10.1177 / 0361198106194800115$

Rammer, C., \& Spielkamp, A. (2015). Hidden champions-driven by innovation: Empirische Befunde auf Basis des Mannheimer Innovationspanels. ZEW-Dokumentation, 15.

Rauch, A., Wiklund, J., Lumpkin, G. T., \& Frese, M. (2009). Entrepreneurial orientation and business performance: An assessment of past research and suggestions for the future. Entrepreneurship Theory and Practice, 33(3), 761-787. https://doi.org/10.1111/j.1540-6520.2009.00308.x

Rehn, A., \& Taalas, S. (2004). 'Znakomstva I Svyazi' (Acquaintances and connections) - Blat , the Soviet Union, and mundane entrepreneurship. Entrepreneurship \& Regional Development, 16(3), $235-250$.

Roberts, J. (2004). The modern firm: Organizational design for performance and growth. Oxford University Press.

Rouyer, E. (2013). Company performance and the two-tier board structure: Empirical evidence from France. International Journal of Business and Economics, 12(1), 45.

Schulze, W. S., Lubatkin, M. H., Dino, R. N., \& Buchholtz, A. K. (2001). Agency relationships in family firms: Theory and evidence. Organization Science, 12(2), 99-116. https://doi.org/10.1287/orsc.12.2. 99.10114

Shepherd, D., \& Haynie, J. M. (2009). Family business, identity conflict, and an expedited entrepreneurial process: A process of resolving identity conflict. Entrepreneurship Theory and Practice, 33(6), 1245 1264. https://doi.org/10.1111/j.1540-6520.2009.00344.x

Shleifer, A., \& Vishny, R. W. (1997). A survey of corporate governance. The Journal of Finance, 52(2), 737-783. https://doi.org/10.1111/j.1540-6261.1997.tb04820.x

Simon, H. (2009). Hidden champions of the 21st century: Success strategies of unknown market-leaders. Springer-Verlag.

Simon, H. (2012). Hidden Champions-Aufbruch Nach Globalia: Die Erfolgsstrategien Unbekannter Weltmarktführer. Campus Verlag.

Sturman, M. C. (1999). Multiple approaches to analyzing count data in studies of individual differences: The propensity for type I errors, illustrated with the case of absenteeism prediction. Educational and Psychological Measurement, 59(3), 414-430. https://doi.org/10.1177/00131649921969956

Tang, J., Tang, Z., \& Cowden, B. J., \& Birton, C. J. (2017). Exploring the relationship between Entrepreneurial orientation, CEO dual values, and SME performance in State-Owned vs. NonstateOwned Enterprises in China. Entrepreneurship Theory and Practice, 41(6), 883-908. https://doi.org/ 10.1111/etap. 12235

Tarko, A. P., Eranky, S., Sinha, K. C., \& Scinteie, R. (1999). An attempt to develop crash reduction factors using regression technique [Paper presentation]. Paper presented at the 78th Annual Transportation Research Board Meeting. National Research Council, Washington, DC.

Temouri, Y. (2012). The Cluster Scoreboard: Measuring the Performance of Local Business Clusters in the Knowledge Economy, OECD Local Economic and Employment Development (LEED) Working Papers, 2012/13. OECD Publishing.

Terjesen, S., Hessels, J., \& Li, D. (2016). Comparative international entrepreneurship: A review and research agenda. Journal of Management, 42(1), 299-344.

Tsoutsoura, M. (2015). The effect of succession taxes on family firm investment: Evidence from a natural experiment. The Journal of Finance, 70(2), 649-688. https://doi.org/10.1111/jofi.12224

UNESCO-UNEVOC. (2012). UNESCO-UNEVOC international centre for technical and vocational education and training. TVET Country Profiles. https://unevoc.unesco.org/home/TVET+Country + Profiles

Vitols, S. (2001). The origins of bank-based and market-based financial systems: Germany, Japan, and the United States. Cornell University Press. 
Voudouris, I., Lioukas, S., Makridakis, S., \& Spanos, Y. (2000). Greek hidden champions:: Lessons from small, little-known firms in Greece. European Management Journal, 18(6), 663-674.

Welter, F. (2011). Contextualizing entrepreneurship - conceptual challenges and ways forward. Entrepreneurship Theory \& Practice, 35(1), 165-184. https://doi.org/10.1111/j.1540-6520.2010. 00427.x

Welter, F., Baker, T., Audretsch, D. B., \& Gartner, W. B. (2017). Everyday Entrepreneurship-A call for entrepreneurship research to embrace entrepreneurial diversity. Entrepreneurship Theory and Practice, 41(3), 311-321. https://doi.org/10.1111/etap.12258

Welter, F., Baker, T., \& Wirsching, K. (2019). Three waves and counting: The rising tide of contextualization in entrepreneurship research. Small Business Economics, 52(2), 319-330. https://doi.org/10.1007/ s11187-018-0094-5

Wiklund, J. (1999). The sustainability of the entrepreneurial orientation-performance relationship. Entrepreneurship Theory and Practice, 24(1), 37-48. https://doi.org/10.1177/104225879902400103

Wiklund, J., \& Shepherd, D. A. (2009). The effectiveness of alliances and acquisitions: The role of resource combination activities. Entrepreneurship Theory and Practice, 33(1), 193-212. https://doi.org/10. $1111 / \mathrm{j} .1540-6520.2008 .00286 . \mathrm{x}$

Williamson, O. E. (1975). Markets and hierarchies, analysis and antitrust implications. Simon \& Schuster.

Wollschlager, N., \& Reuter-Kumpmann, H. (2004). From divergence to convergence: A history of vocational education and training in Europe. European Journal: Vocational Training, 32(1), 6-17. https://doi. org/10.1515/ECFR.2006.019

Wright, M., Liu, X., Buck, T., \& Filatotchev, I. (2008). Returnee entrepreneurs, science park location choice and performance: An analysis of high-technology SMEs in China. Entrepreneurship Theory and Practice, 32(1), 131-155. https://doi.org/10.1111/j.1540-6520.2007.00219.x

Zahra, S. A. (2005). Entrepreneurial risk taking in family firms. Family Business Review, 18(1), 23-40. https://doi.org/10.1111/j.1741-6248.2005.00028.x

\section{Author Biographies}

David B. Audretsch is a Distinguished Professor and Ameritech Chair of Economic Development at Indiana University, where he is also serves as Director of the Institute for Development Strategies. He also is a part time Professor at the Department of Innovation Management and Entrepreneurship, University of Klagenfurt, Austria and an Honorary Professor of Industrial Economics and Entrepreneurship at the WHU-Otto Beisheim School of Management in Germany. Audretsch's research has focused on the links between entrepreneurship, government policy, innovation, economic development and global competitiveness. He is co-author of The Seven Secrets of Germany, published by Oxford University Press. He is co-founder and Editor-in-Chief of Small Business Economics: An Entrepreneurship Journal. He was awarded the Global Award for Entrepreneurship Research by the Swedish Foundation for Entrepreneurship. He has received honorary doctorate degrees from the University of Augsburg, Jonköping University and the University of Siegen. Audretsch also was awarded the Schumpeter Prize from the University of Wuppertal. Audretsch has consulted with numerous international organizations, including the World Bank, OECD, European Union and the United Nations. He currently serves as a member of the Advisory Board to a number of research and policy institutes, including the Swedish Entrepreneurship Forum in Stockholm, the Jackstädt Centre for Entrepreneurship in Wuppertal, Germany, and the American Center for Entrepreneurship in Washington, D.C.

Erik E. Lehmann is a Full Professor of Management and Organization at Augsburg University, Germany and Director of the Program Global Business Management (GBM), and Dean of Student Affairs. He received his doctoral degree 1999 from Rostock University and his 
habilitation (venia legendi) from Konstanz University in 2005. From 2004-2005 he joined the Max Planck Institute (Jena) as an assistant director. Lehmann's research is focused on the links between corporate governance in family and entrepreneurial firms, innovation, public policy, education and innovation systems, financial constraints and regional and global competition. He serves as an associate editor of Small Business Economics: An Entrepreneurial Journal. His research has been published in leading academic journals like Review of Finance, Research Policy, Entrepreneurship Theory and Practice, Journal of Economic Behavior and Organization, Small Business Economics: An Entrepreneurship Journal, Journal of Small Business Management, Review of Accounting and Finance, Journal of Technology Transfer among others. His most recent books include The Seven Secrets of Germany: Economic Resilience in an Era of Global Turbulence (Oxford University Press, with David B. Audretsch) or The Routledge Companion to the Makers of Modern Entrepreneurship (Routledge, edited volume with David B. Audretsch).

Julian Schenkenhofer is a research associate at the University of Augsburg, Chair of Management and Organization. In his research, Schenkenhofer examines German Mittelstand companies that pursue a niche strategy and are commonly known as hidden champions. His research has been published in various academic journals such as the Multinational Business Review, Small Business Economics: An Entrepreneurship Journal or the European Journal of Higher Education, among others. Moreover, has been a peer reviewer for the latter journals in several article submissions. 